\title{
EFEKAT FACIJALNE EKSPRESIJE EMOCIJA, TIPA I NIVOA MOĆI NA ZAKLJUČIVANJE O DOMINANTNOSTI OPAŽENE OSOBE ${ }^{2}$
}

\begin{abstract}
Apstrakt
Zaključivanje o dominantnosti opažene osobe predstavlja važan proces koji potpomaže regulaciju socijalne interakcije. Dosadašnja istraživanja pokazuju da se o dominantnosti socijalnih aktera može zaključivati na osnovu raznih socijalnih znakova, među kojima je i facijalna ekspresija emocija. Dok se na osnovu opažene ljutnje najčešće zaključuje o prisustvu visoke, a na osnovu opažene tuge - prisustvu niske dominantnosti, opažanje sreće ne daje tako jednoznačne impresije. U cilju postizanja jasnije slike, u razmatranje su uzeti i tip i nivo moći koji opažena osoba poseduje, konkretno, moć nagrađivanja i stručnjačka moć, a koje mogu biti visoko i nisko izražene. U istraživanju je učestvovalo100 ispitanika $\left(N_{\text {žna }}=71\right)$, studenata prve i druge godine psihologije. Primenjen je $3 \times 2 \times 2$ potpuno ponovljeni nacrt Ekspresija emocije (sreća vs. bes vs. tuga) x Tip moći (nagrađivanja vs. stručnjačka) x Nivo moći (visok vs. nizak). Dominantnost je predstavljala zavisnu varijablu, koja je operacionalizovana preko skale semantičkog diferencijala. Stimulus materijal činile su fotografije lica ujednačene po polu i starosti, na kojima su bile prisutne pomenute facijalne ekspresije. Rezultati su ukazali na značajnu trostruku interakciju između ispoljene emocije, tipa i nivoa moći. Kada je u pitanju moć nagrađivanja, primećena je značajna interakcijaispoljene emocije i nivoa moći na stepen pripisane dominantnosti, dok se u okviru stručnjačke moći uočava jedino glavni efekat ekspresije emocija. Dobijeni nalazi tumačeni su u skladu sa različitim očekivanjima ispitanika koja se formiraju tokom procesa socijalizacije. Može se zaključiti da ukoliko želimo da bliže upoznamo mehanizam u osnovi efekta koji ekspresija emocija ima na opažanje dominantnosti, u razmatranje treba uzeti i zanimanje koje opažena osoba obavlja.

Ključne reči: facijalna ekspresija emocija, tip moći, nivo moći, dominantnost
\end{abstract}

\section{Uvod}

Fenomen dominantnosti okupira pažnju istraživačarazličitih oblasti psihologije. Oni koji mupristupaju iz ugla socijalne percepcije, često su posvećeni pitanju može li

\footnotetext{
${ }^{1}$ stefan.djoric@filfak.ni.ac.rs

Citirati rad na sledeći način: Đorić, S. (2021). Efekat facijalne ekspresije emocija, tipa i nivoa moći na zaključivanje o dominantnosti opažene osobe. Godišnjak za psihologiju, 18, 123-136. https://doi. org/10.46630/gpsi.18.2021.08

${ }^{2}$ Deo istraživanja prikazan je na konferenciji Dani primenjene psihologije 2018, koja je organizovana od strane Departmana za psihologiju Filozofskog fakulteta u Nišu.
} 
se, i na osnovu kojih socijalnih znakova u socijalnoj interakciji zaključivati o stepenu dominantnosti opažene osobe. Tako je, recimo,primećeno da se izvijene obrve i direktno gledanje u oči interpretiraju kao znaci visoke dominantnosti (Carneyet al., 2005; Hallet al., 2005), maskulinost lica takođe (Boothroydet al., 2007), aodsustvo fizičke snage kao signal submisivnosti (Toscanoet al., 2016).

U određenom broju studija primećeno je da se na osnovu facijalne ekspresije, takođe, zaključuje o dominantnosti opažene osobe. Tako je uočena tendencija socijalnih aktera da osobi koja ispoljava ljutnju pripisuju visoku dominantnost, dok se osobama koje ispoljavaju tugu najčešće pripisuje niska (Hareliet al., 2009; Ueda \& Yoshikawa, 2017; Knutson, 1996). Kada je u pitanju osmeh, čini se da rezultati ne postižu jasan konsenzus. Dok su određeni radovi pokazali da se ova ekspresija opaža kao signal niske dominantnosti (Halberstadt \& Saitta, 1987; Ueda \& Yoshikawa, 2017), bilo je i onih koji su ukazivali na suprotno (Knutson, 1996; Montepare \& Dobish, 2003). U meta-analizi Halove i saradnika takođe je iznešen zaključak da se ljudi koji se osmehuju opažaju kao niže dominantni, ali su autori istakli da se radi o visoko heterogenom efektu. Opisani rezultati ukazuju na potrebu za ispitivanjem moderirajućih efekata drugih situacionih i individualnih faktora (Hall et al., 2005). U tom smislu, primećeno je, recimo, da se opažanje emocija i pripisivanje dominantnosti može razlikovati u zavisnosti od pola opažene osobe (Becker et al., 2007), ili njene rase (Hugenberg \& Bodenhausen, 2003). Relevantni moderatori koji se mogu uzeti u razmatranje su tip, i nivo moći koje opažena osoba poseduje (Carney, 2020).

\section{Pojam moći i njegovo razgraničenje od pojma dominantnosti}

Teško je dati preciznu definiciju moći. Iako joj se pripisuje prožimajući uticaj, postoje pitanja koja otežavaju njeno određenje. Na primer,da li moć podrazumeva uticaj na odluke ljudi zato što utiče na njihova psihička stanja, ili ona uključuje i neposredan uticaj na akcije i postupke? Gde je moć smeštena? U onome ko je primenjuje, ili onome nad kime se primenjuje? Uz svest o navedenim dilemama, u ovom su radu sporni fenomeni shvaćeni u svetlu određenja koje daje Karnijeva: Moć predstavlja pristup resursima i stepen kontrole koji neko ima nad novčanim i/ili socijalnim ishodima druge osobe.Sa druge strane, dominantnost se može definisati kao crta ličnosti koja se manifestujeu težnji da se traži i upražnjava moć, status ili uticaj (Carney, 2020). Dakle, iako su različiti, moć i dominantnost su usko povezani konstrukti.Ova činjenica, često je bila još jedan od izvora kontradiktornih nalaza u prisutnoj literaturi. U pojedinim radovima, uočava se tendencija autora da izjednačavaju ove termine međusobno, ali i sa drugim terminima poput statusa i/ili uticaja. Takvi postupci u metodologiji istraživanjadodatno otežavaju mogućnost bližeg upoznavanja efekata koji pomenuti konstrukti mogu imati na ponašanje osoba $u$ socijalnoj interakciji (Carney, 2020; Hall et al., 2005).

\section{Tipovi moći}

Imajući u vidu da moć može biti multidimenzionalni konstrukt, u pokušaju da postignu određenu dozu sistematičnosti Frenč i Rejven (French \& Raven, 1959) razvijaju taksonomiju. Da bi neko mogao imati moć, potrebno je da poseduje određene 
karakteristike koje mu tu moć obezbeđuju. Kada govorimo o raspolaganju svojstvima koje omogućavaju korišćenje moći, govorimo zapravo o izvorima moći. Autori razlikuju 6 tipova moći prema njihovom izvoru: 1. Moć nagrađivanja, 2. Moć prisile, 3. Referentna moć, 4. Stručnjačka moć, 5.Legitimna moć, 6. Moć informisanosti. U ovom istraživanju akcenat je stavljen na moći nagrađivanja i stručnjačkoj moći.

Moć nagrađivanja podrazumeva da osoba $\mathrm{O}$ ima mogućnost da osigura neku korist ili zadovoljstvo za osobu P. Pri tome je potrebno da a) Osoba P ocenjuje da osoba $\mathrm{O}$ poseduje mogućnost da nagradi b) Osoba $\mathrm{O}$ zna da određeni način njenog ponašanja (obezbeđivanje nagrade) izaziva kod osobe prihvatanje zahteva koje osoba O postavlja. Sredstva nagrađivanja mogu se odnositi na veći novčani dohodak, unapređenje, ili višu školsku ocenu.

Stručnjačka moć počiva na oceni osobe $\mathrm{P}$ da osoba $\mathrm{O}$ poseduje znanje $\mathrm{i}$ kompetentnost. Osoba može manifestovati ovu moć kroz reputaciju, potvrde koje dokazuju stručnost ili kroz direktnu akciju (French \& Raven, 1959).

Prema našem saznanju, do sada nisu sprovedena istraživanja koja bi se konkretno posvetila odnosu ispoljene emocije, tipa i nivoa određenog tipa moći, kao i njihovom uticaju na formiranje impresije o dominantnosti opažene osobe. U istraživanju sličnog problema, grupa istraživača proučavala jeda liodsustvo naspram nervoznog facijalnog izraza predstavljaju signal za neki od 6 tipova moći koji su Frenč i Rejven opisali (French \& Raven, 1959). Autori su došli do zaključka da su ispitanici pripisivali viši stepen moći svim tipovima moći (osim moći prisile) kada na licu nije bilo ekspresije, nego onda kada se na licu mogla opažati nervoza (Aguiniset al., 1998). Objašnjenje za navedene rezultate našli su u različitim očekivanjima o neverbalnoj komunikaciji tipova moći, a koja se formiraju u procesu socijalizacije. Do sličnih rezultata došla je i Luisova primetivši da je neutralno lice menadžera bio signal povišeneefikasnosti, u poređenju sa licima menadžera na kojima se mogla primetiti emocija sreće ili besa (Lewis, 2000).

Problem ovog istraživanjabio je ispitati kako facijalna ekspresija emocija može uticati na opažanje dominantnosti. Imajući u vidu prisutne kontradiktornosti u postojećoj literaturi na ovu temu, u razmatranje je uzet i moderirajući efekat tipa i nivoa (količine) moći koji opažena osoba poseduje. S obzirom na njenu relevatnost u kontekstu dominantnosti,cilj istraživanja bio je pružiti iznijansiranu sliku o tome zašto, i u kojoj meri, nekoga opažamo kao manje, a nekoga kao više dominantnog. Preciznije rečeno, svrha istraživanja bila je ispitati glavni efekatekspresije emocija,kao i moderirajuće efekte tipa moći i nivoa moći koji opažena osoba poseduje na stepen pripisane dominantnosti.

\section{Metod}

\section{Nacrt}

Eksperiment je zasnovan na $3 \times 2 \times 2$ potpuno ponovljenomnacrtu sa varijablama Ekspresija emocije (Sreća, Ljutnja, Tuga) xTip moći (nagrađivanja, stručnjačka) xNivo moći (visok, nizak). 


\section{Stimulus materijal i operacionalizacija varijabli}

Stimulus materijal činilo je 48 fotografija muških i ženskih lica starosti od 20 do 30 godina $(A S=25)$ na kojima se vidi ekpresija ljutnje (16), ekspresija tuge (16) i sreće (16). Na fotografijama se nalazio podjednak broj muškaraca i žena (24 žena, 24 muškaraca). Ispod svake fotografije vidljivo je jedino zanimanje osobe, koje predstavlja operacionalizaciju određenog tipa, tj. nivoa moći: 1. direktor, 2. kurir (visok i nizak nivo moći nagrađivanja) 3. naučnik, 4. student i godine studija (visok i nizak nivo stručnjačke moći). Fotografije prikazuju lice osobe do ramena, a preuzete su iz AKDEF (Averaged Karolinska Directed Emotional Faces) baze (Lundqvist \& Litton, 1998).

\section{Varijable}

Status zavisne varijable imao je stepen pripisane dominantnosti,dok je ekspresija emocija bila nezavisna, a tip i nivo moći tretirani su kao potencijalni moderatori.

Instrument je činila Skala semantičkog diferencijala kreirana za potrebe istraživanja. Na sedmostepenoj skali, ispitanici odlučuju u kojoj meri je dominantnost/ submisivnost zastupljena kod osobe sa fotografije. S obzirom na to da ljudi retko koriste termine dominantnost/ submisivnost u svakodnevnom govoru, ova dimenzijaje razložena na sledeće parove prideva: Snažan - Slab, Silovit - Bojažljiv, Kontrolišući Nekontrolišući, Samopouzdan - Nesamopouzdan.Pridevi su preuzeti iz liste 69 najčešće korišćenih termina u opisivanju ličnosti koju su formirali Rot i Havelka (1969), a birani su tako da u skladu sa rečnicima (npr. Ćosić, 2008) predstavljaju sinonime za termin moći ili dominatnost. Ukupan skor procenjenedominantnosti formiran je kao prosek skorova na pomenutim dimenzijama, a koeficijent interne konzistencije izražen preko koeficijenta Krombah alfa u ovom radu iznosi $\alpha=.70$. U cilju sprečavanjarazumevanja cilja ispitivanja od strane ispitanika o tome šta je cilj istraživanja (procena dominantnosti/ submisivnosti), pored ovih prideva dodata su još 3 para, irelevantna za problem ovog istraživanja: Inteligentan - Neinteligentan, Pošten - Nepošten, Mudar - Lakomislen.

\section{Procedura \\ Formiranje kategorija varijabli Tip i Nivo moći (Pilot faza)}

U ovoj fazi učestvovalo je 10 studenata završnih godina studija psihologije,čiji zadatak je bio da iz većeg broja ponuđenih zanimanja izdvoje ona koja smatraju tipičnim predstavnicima ponuđenih tipova moći.Lista zanimanja formirana je na osnovu spiskova koji su dostupni širom internet stranica poput www.poslovi.infostud.com, www. careerdimension.com i sl.Ispitanici su najpre upoznati sa konceptom moći nagrađivanja i stručnjačke moći, a potom su iz liste od 200 zanimanja napravili samo po jedan izbor, odabravši zanimanje koja smatraju tipičnim predstavnikom visoke i niske stručnjačke, odnosno, tipičnim predstavnikom visoke i niske moći nagrađivanja. Zanimanja koja su najčešće odabrana od strane svih učesnika, uključena su u stimulus materijal.Deset učesnika iz pilot fazenije učestvovalo u glavnoj fazi istraživanja. 


\section{Glavna faza}

Istraživanje je sprovedeno u prostorijama fakulteta koje su opremljene kompjuterima. Svi ispitanici dali su informisanu saglasnost, a usmeno im je saopšteno da istraživanje ima za cilj da ispita kako ljudi opažaju druge ljude u svakodnevnom okruženju. Ispitanik je na ekranu ispred sebe video svih 48 fotografija ( 24 fotografije po tipu moći, odnosno, 12 fotografija za visoku i 12 fotografija za nisku moć nagrađivanja, i 12 fotografija za visoku i 12 fotografija za nisku stručnjačku moć), a njegov zadatak je bio da na skali semantičkog diferencijala odabere $u$ kojoj meri smatra da je svaki od ponuđenih prideva prisutan kod osobe sa fotografije. Svaku fotografiju ispitanik je posmatrao u trajanju od 60 sekundi, nakon čega bi slika nestala, a ispitanik bi popunjavao svesku sa ponuđenim opozitnim pridevima. Kada završi sa davanjem procene, klikom na dugme „space” prelazio bi na sledeću fotografiju. Ispitanici su na kraju obavešteni o anonimnosti ispitivanja i tome da će podaci biti korišćeni u istraživačke svrhe. S obzirom na to da u trenutku sprovođenja studije (2015. godine) nije postojala formalna Etička komisija, etička ispravnost rada je proverena i odobrena od strane dvoje profesora iz oblasti Socijalni psihologije i Socijalne percepcije, a istraživanje sprovedeno u skladu sa etičkim standardima psihološke istraživačke prakse.

\section{Uzorak}

Uzorak je prigodan, sačinjen od 100 ispitanika $\left(\mathrm{N}_{\text {muškaraca }}=29\right)$, studenata prve i druge godine psihologije. Iz početnog uzorka (102), isključeno je dvoje ispitanika čije su vrednosti predstvljale multivarijantne autlejere.

\section{Rezultati}

Pri statističkoj obradi podataka korišćena je višestruka ANOVA za ponovljena merenja.

Rezultati provere glavnih i interakcijskih efekata nezavisne i moderatorskih varijabli prikazani su u tabeli 1. Mošlijev test je pokazao da uslov za sferičnost nije ispunjen kada je u pitanju varijabla ispoljene emocije (Mauchly's $W=0.83, p=.014$, kao ni trostruka interakcija pomenutih varijabli (Mauchly's $W=0.83, p=.019$ ). Zbog toga su u podaci analizirani u skladu sa Hajn-Felt (Huynh-Feldt) korekcijom.

\section{Tabela 1}

Glavni i interakcijski efekti ekspresije emocija, tipa i nivoa moći na pripisanu dominantnost

\begin{tabular}{lcccc}
\hline & $d f$ & $F$ & $p$ & $\eta_{2} p$ \\
\hline Emocija & $(1.77,83.09)$ & 79.58 & $<.001$ & .63 \\
Tip moći & $\left(1,98^{3}\right)$ & 11.75 & .001 & .20 \\
Nivo Moći & $(1,98)$ & 52.38 & $<.001$ & .53 \\
Emocija * Tip moći & $(2,196)$ & 3.82 & .026 & .08
\end{tabular}

\footnotetext{
${ }^{3}$ Parametri nisu korigovani u skladu sa Hajn-Felt korekcijom, jer je kod varijabli sa dve kategorije uslov o sferičnosti uvek ispunjen.
} 


\begin{tabular}{lcccc} 
Emocija * Nivo moći & $(2,196)$ & 10.43 & $<.001$ & .18 \\
Tip moci * Nivo moći & $(1,98)$ & 23.60 & $<.001$ & .33 \\
Emocija * Tip moći * nivo moći & $(1.76,165.48)$ & 12.06 & $<.001$ & .20 \\
\hline
\end{tabular}

Napomena. $d f=$ stepni slobodne; $F=F$ količnik; $\eta_{\mathrm{p}}^{2}=$ parcijalna kvadrirana eta (mera veličine efekta).

S obzirom na to da je analiza ukazala na značajnu trostruku interakciju, u daljem radu su interaktivni efekti ekspresije emocije i nivoa moći na pripisanu dominantost posmatrani odvojeno, u okviru svakog od tipova moći (tj. u okviru moći nagrađivanja i stručnjačke moći). U nastavku su spomenuti samo post hok efekti koji se smatraju relevantnim sa stanovišta problema istraživanja, a kompletna tabela može se naći uPrilogu (tabele1 i 2 u prilogu). Imajući u vidu prisustvo velikog broja međusobnih poređenja, primenjena je Tukey korekcija.

Posmatrajući najpre efekte u okviru moći nagrađivanja (grafikon1) može se primetiti da su tužna lica $\left(A S_{\text {direktor }}=6.77, A S_{\text {kurir }}=5.77\right)$, očekivano, opažana kao značajno manje dominantna od lica koja ispoljavaju sreću i ljutnju, bez obzira na nivo moći. Dalje, analizirajući post hoc efekte,uočava se da su ispitanici direktorima na čijem licu je opažena sreća $(A S=9.51)$ pripisali značajno niži stepen dominantnosti od direktora na čijem licu se nalazila ekspresija ljutnje $(A S=10.72)$. Sa druge strane, ovaj obrazac nije primećen pri opažanju kurira, gde se značajne razlike između opažene sreće $(A S=8.95)$ i ljutnje $(A S=8.04)$ ne manifestuju. Ako se efekti interakcije sagledaju iz ugla preseka po varijabli ekspresija emocije, primećuje se da nema značajnih razlika u pripisanoj dominantnostiizmeđu direktora i kurira kada je u pitanju emocija sreće $(p=.603)$. Sa druge strane, uočavaju se značajno različiti skorovi kada su u pitanju ekspresija tuge i ljutnje $(p<.001)$. Konkretno, direktori koji ispoljavaju ljutnju opaženi su kao dominantniji od kurira koji ispoljavaju ovu emociju, a isti odnos skorova uočen je i kada je ekspresija tugeu pitanju.

\section{Grafikon1}

Interakcijski efekat ispoljene emocije i nivoa moći na pripisanu dominantnost u okviru moći nagrađivanja

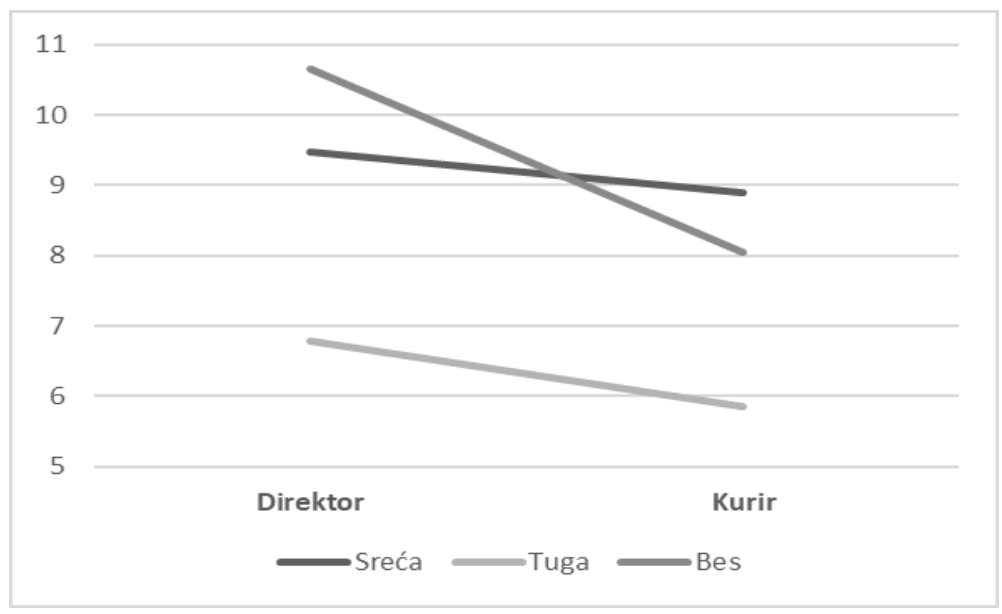


Kada je reč o analiziefekata u okviru stručnjačkog tipa moći, rezultati ukazuju da nivo moći nije statistički značajno moderirao efekat ekspresije emocije na pripisivanje dominantnosti (Grafikon 2).Bez obzira na to da li je opažena osoba naučnik ili student, sreća $\left(A S_{\text {naučnik }}=9.26, A S_{\text {student }}=9.18\right)$ i ljutnja $\left(A S_{\text {naučnik }}=8.73\right.$, $\left.A S_{\text {student }}=8.68\right)$ međusobno nisu ocenjene kao značajno različiti signali dominantnosti. Sa druge strane, emocija tuge i kod jednog $\left(A S_{\text {naučnik }}=6.38\right)$ i kod drugog $\left(A S_{\text {student }}\right.$ = 5.66) nivoa moći opažena je kao znak značajno niže dominantnosti u odnosu na ona lica koja su iskazivala sreću ili ljutnju. Međusobnim poređenjenjem nivoa moći u okviru stručnjačkog tipa, primećuje se da ispitanici ne pripisuju naučnicima i studentima značajno različite skorove u pogledu dominantnosti, bez obzira na to koju emociju ispoljavaju opažena lica sa stimulus materijala.

\section{Grafikon 2}

Interakcijski efekat ispoljene emocije i nivoa moći na pripisanu dominantnost u okviru stručnjačke moći

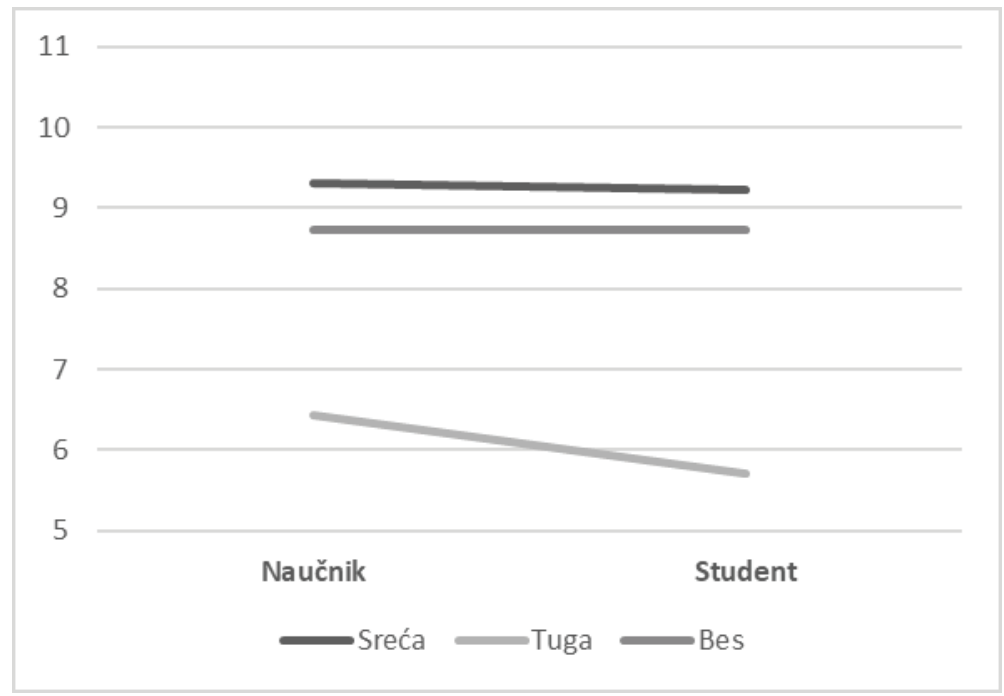

\section{Diskusija}

Cilj istraživanja bio je ispitati kako facijalna ekspresija emocija, zajedno sa tipom i nivoom(količinom) određenog tipa moći opažene osobe mogu uticati na percepciju njene dominantnosti. Rezultati su pokazali da ispoljene emocije mogu rezultirati različitim impresijama u zavisnosti od zanimanja opažene osobe. No, ovaj obrazac primećen je samo kada je u pitanju moć nagrađivanja i stepen u kome je ona izražena, ali ne i kada je u pitanju stručnjačka moć.

Pre svega, u radu je primećeno da kada direktori ispoljavaju ljutnju, to se opaža kao signal više dominatnosti nego kada ispoljavaju sreću. Sa druge strane,ovaj obrazac nije primećen pri opažanju kurira, gde su poređeni skorovi na 
pomenutim emocijama ostali ispod nivoa statističke značajnosti. Opisani nalazi moguukazivatinaprisustvo stereotipa, a time i različitih očekivanjao tome šta signaliziraju pojedine ekspresije emocijau zavisnosti odnivoa moći opaženog aktera. $\mathrm{Na}$ primer, manifestacija sreće možebitipercipirana kao signal naivnosti. Ovo tumačenje zasnovano je na pretpostavci da se srećni ljudi ređe upuštaju u produbljenu analizu i traženje negativnih informacija (Baraschet al., 2016). Stoga su direktori sa ekspresijom osmeha mogli biti opaženi kao lakomi, pogodni za eksploataciju, što je dovelo do toga da njihovi skorovi na dominantnosti budu niži od skorovadirektora koji su ispoljavali bes.Ostaje pitanje zbog čega odnos između ispoljene ljutnje i sreće i kod kurira nije opažen na isti način? Uz svest o njegovoj spekulativnosti, može se ponuditi sledeće objašnjenje: Emocijabesanajčešćeje definisana kao afekat negativne valence koji se javlja kao posledica blokade ka dostizanju željenog cilja (npr.Berkowitz, 1993; Carver \& Harmon - Jones, 2009). S obzirom na to da se radi o osobi niske moći nagrađivanja, moguće je da su ispitanicikurire opažali kao nekoga ko će zbog učestalog nedostatka resursa otežano moći da otkloni blokadu. Sa druge strane, imajući u vidu da su bogatiji u resursima, direktori se mogu slobodnije ponašati u skladu sa sopstvenim namerama, zbog čega su ispitanici besne direktore opažali kao sposobnije (dominantnije) da otklone prepreku koja je izazvala ovo osećanje (Ratcliffet al., 2012).

Nivo zastupljenosti stručnjačke moć nije se pokazao kao moderator efekta koji je ekspresija emocije imala na opažanje dominantnosti. Sva lica na kojima je bila prisutna ekspresija srećei ljutnje opažana su kao dominantnija od lica koja su ispoljavala tugu. Između lica koja su ispoljavala sreću i ljutnju, pak, nije bilo značajnih razlika. Ni sami naučnici nisu bili opaženi kao značajno dominantniji od studenata, niti obrnuto. Navedeni rezultati mogu se protumačiti u svetlu definicije dominantnosti, koju treba razumeti kao relativno trajnu dispoziciju ličnosti. Odsustvo značajnih razlika, i ovog puta, može se pripisati različitim očekivanjima formiranimtokom procesa socijalizacije. Ispitanici su mogli biti svesni da naučnici imaju veću moć od studenata, ali ta moć nije stečena dominantošću (Hall et al., 2005; Keltner et al., 2003). Konkretno, naučnik može imati mnogo znanja, što ga čini moćnim, ali to ne mora da znači da se radi o snažnoj, silovitoj, kontrolišućoj i samopouzdanoj osobi. Naprotiv, istraživanja pokazuju da su naučnici često opaženi kao introvertni, socijalno povučeni, trapavi, ali inteligentni i radoznali ljudi (npr. Schinskeet al., 2015; Tintori \& Palombra, 2017).

Određena ograničenja sprovedenog istraživanja otežavaju donošenje generalizabilnih zaključaka. Pre svega, u uzorku postoji nejednak broj muških i ženskih ispitanika. Polne razlike u pripisivanju dominatnosti se (iako nekonzsistentno) sreću u literaturi, pa se stoga mogu i očekivati. Budućim istraživačima se preporučuje dosezanje uzorka koji će eliminisati dejstvo ove konfundirajuće varijable. Treba imati u vidu i da se uzorak u pilot i glavnoj fazi istraživanja sastojao od studenata, što dodatno otežava mogućnost uopštavanja nalaza izvan ove populacije. Dalje, postoji dilema oko toga da li se osmeh može uvek smatrati pouzdanim indikatorom sreće. Iako se osmeh najčešće opaža kao signal ove emocije, to nije uvek slučaj. Osmeh je jedan od najkompleksnijih facijalnih izraza koji je visoko uslovljen kontekstom u 
kome se javlja (La Franceet al., 2003). Ova ekspresija može imati različite forme, tako da danas razlikujemo čak 18 vrsta osmeha (koketni, prezrivi, prigušeni, paćenički, itd.) (Kostić, 2006). On zaista može odražavati emociju sreće, ali ljudi se osmehuju i kada im je neprijatno (Ochanomizu, 1991) i kada su nesrećni (Ekman \& Friesen, 1982). Dobijeni rezultati u istraživanju mogu biti posledica različitog percipiranja ovog socijalnog znaka. Iako pogled na fotografije iz AKDEF baze ostavlja utisak da su autori vodili računa da stimulus materija bude ujednačen i u tom smislu, ne može se tvrditi sa apsolutnom sigurnošću da su svi ispitanici tumačili osmeh na isti način.

\section{Zaključak}

Rezultati istraživanja još jednom potvrđuju da se učesnici socijalnih interakcija prilikom opažanja drugih ljudi oslanjaju na interpretaciju facijalnih ekspresija sa ciljem da zaključe o dominantnosti. Orijentišući se na specifičan kontekst u kome je posmatraču poznato i zanimanje opažene osobe, nalazi ovog istraživanja ukazuju na relevantnost i tipa, kao I nivoa određenog tipa moći koji ona poseduje. Rezultati predstavljaju polazište za dodatna istraživanja koja će još snažnije doprineti spoznavanjumehanizma koji se nalazi u osnovi procesa formiranja impresije o dominantnosti.

\section{Literatura}

Aguinis, H., Simonsen, M. M., \& Pierce, C. A. (1998). Effects of nonverbal behavior on perceptions of power bases. The Journal of Social Psychology, 138(4), 455-469. https://doi.org/10.1080/00224549809600400

Barasch, A., Levine, E. E., \& Schweitzer, M. E. (2016). Bliss is ignorance: How the magnitude of expressed happiness influences perceived naiveté and interpersonal exploitation. Organizational Behavior and Human Decision Processes, 137, 184 206. https://doi.org/10.1016/j.obhdp.2016.05.006

Becker, D. V., Kenrick, D. T., Neuberg, S. L., Blackwell, K. C., \& Smith, D. M. (2007). The confounded nature of angry men and happy women. Journal of Personality and Social Psychology, 92(2), 179-190. https://doi.org/10.1037/0022-3514.92.2.179

Berkowitz, L. (1993). Aggression: Its causes, consequences, and control. Mcgraw-Hill Book Company.

Boothroyd, L. G., Jones, B. C., Burt, D. M., \& Perrett, D. I. (2007). Partner characteristics associated with masculinity, health and maturity in male faces. Personality and Individual Differences, 43(5), 1161-1173. https://doi.org/10.1016/j.paid.2007.03.008

Carver, C. S., \& Harmon-Jones, E. (2009). Anger is an approach-related affect: Evidence and implications. Psychological Bulletin, 135(2), 183-204. https://doi.org/10.1037/ a0013965

Carney, D. R., Hall, J. A., \& LeBeau, L. S. (2005). Beliefs about the nonverbal expression of socialpower. Journal of Nonverbal Behavior, 29(2), 105-123. https://doi. org/10.1007/s10919-005-2743-Z 
Carney D. R. (2020). The nonverbal expression of power, status, and dominance. Current opinion in psychology, 33, 256-264. https://doi.org/10.1016/j.copsyc.2019.12.004

Ćosić (2008). Rečnik sinonima.KORNET, Prometej.

Ekman, P., \& Friesen, W. V. (1982). Felt, false, and miserable smiles. Journal of Nonverbal Behavior, 6(4), 238-258. https://doi.org/10.1007/BF00987191

French Jr., J. R. P., \& Raven, B. H. (1959). The bases of social power. In D. Cartwright (Ed.), Studies in social power (pp. 150-167). Institute for Social Research.

Hall, J. A., Coats, E. J., \& LeBeau, L. S. (2005). Nonverbal behavior and the vertical dimension of social relations: a meta-analysis. Psychological bulletin, 131(6), 898924. https://doi.org/10.1037/0033-2909.131.6.898

Halberstadt, A. G., \& Saitta, M. B. (1987). Gender, nonverbal behavior, and perceived dominance: A test of the theory. Journal of Personality and Social Psychology, 53(2), 257-272. https://doi.org/10.1037/0022-3514.53.2.257

Hareli, S., Shomrat, N., \& Hess, U. (2009). Emotional versus neutral expressions and perceptions of social dominance and submissiveness. Emotion, 9(3), 378-384. https://doi.org/10.1037/a0015958

Hugenberg, K., \& Bodenhausen, G. V. (2003). Facing Prejudice: Implicit Prejudice and the Perception of Facial Threat. Psychological Science, 14(6), 640-643. https://doi. org/10.1046/j.0956-7976.2003.psci_1478.x

Keltner, D., Gruenfeld, D. H., \& Anderson, C. (2003). Power, approach, and inhibition. Psychological Review, 110(2), 265-284. https://doi.org/10.1037/0033295X.110.2.265

Kostić A., (2006). Govor lica. Filozofski fakultet Niš.

Knutson, B. (1996). Facial expressions of emotion influence interpersonal trait inferences. Journal of Nonverbal Behavior, 20(3), 165-182. https://doi.org/10.1007/ BF02281954

LaFrance, M., Hecht, M., Paluck, E. (2003). The Contingent smile: A meta - analysis of sex differences in smiling. Psychological bulletin, 129(2),305 - 334https://doi. org/10.1037/0033-2909.129.2.305

Lewis, K. M. (2000). When leaders display emotion: How followers respond to negative emotional expression of male and female leaders. Journal of Organizational Behavior, 21, 221-234.https://doi.org/10.1002/(SICI)1099-1379(200003)21:2<221::AIDJOB36>3.0.CO;2-0

Lundqvist, D., \& Litton, J. E. (1998). The Averaged Karolinska Directed Emotional Faces - AKDEF, CD ROM from Department of Clinical Neuroscience, Psychology section, Karolinska Institutet, ISBN 91-630-7164-9

Mast, M. S., \& Hall, J. A. (2004). When is dominance related to smiling? Assigned dominance, dominance preference, trait dominance, and gender as moderators. Sex Roles: A Journal of Research, 50(5-6), 387-399. https://doi.org/10.1023/ B:SERS.0000018893.08121.ef

Montepare, J. M., \& Dobish, H. (2003). The Contribution of Emotion Perceptions and Their Overgeneralizations to Trait Impressions. Journal of Nonverbal Behavior, 27(4), 237-254. https://doi.org/10.1023/A:1027332800296 
Ochanomizu, U. (1991). Representation forming in Kusyo behavior. Japanese Journal of Developmental Psychology, 2, 25-31.

Ratcliff, N. J., Franklin, R. G., Nelson, A. J., Jr., \& Vescio, T. K. (2012). The scorn of status: A bias toward perceiving anger on high-status faces. Social Cognition, 30(5), 631-642. https://doi.org/10.1521/soco.2012.30.5.631

Rot, N., Havelka, N.N. (1967) Broj naziva korišćenih u ocenjivanju osobina ličnosti i osobine koje se njima najčešće ocenjuju. Psihologija, 1(1), str. 47-60.

Schinske, J., Cardenas, M., \& Kaliangara, J. (2015). Uncovering Scientist Stereotypes and Their Relationships with Student Race and Student Success in a Diverse, Community College Setting. CBE life sciences education, 14(3), Article 35.https:// doi.org/10.1187/cbe.14-12-0231

Tintori, A., \& Palomba, R. (2017). Turn on the light on science: A research-based guide to break down popular stereotypes about science and scientists. Ubiquity Press.

Toscano, H., Schubert, T. W., Dotsch, R., Falvello, V., \& Todorov,A. (2016). Physical strength as a cue to dominance: A data-driven approach. Personality and Social Psychology Bulletin, 42(12), 1603-1616. https://doi.org/10.1177/0146167216666266

Ueda, Y., Nagoya, K., Yoshikawa, S., \& Nomura, M. (2017). Forming Facial Expressions Influences Assessment of Others' Dominance but Not Trustworthiness. Frontiers in psychology, 8, Article 2097. https://doi.org/10.3389/fpsyg.2017.02097

\author{
Stefan Đorić ${ }^{4}$ \\ Departman of Psychology \\ Faculty of Philosophy \\ University of Niš \\ Niš, Serbia
}

\title{
THE EFFECT OF FACIAL EXPRESSION OF EMOTION, TYPE AND LEVEL OF POWER ON INFERENCES OF PERCEIVED DOMINANCE
}

\begin{abstract}
Drawing inferences of the perceived dominance of individuals is an important process which helps to regulate social interaction. Existing research indicates that inferences of the dominance of social actors can be drawn based on various social cues, including facial expression of emotion. While perceived anger usually leads to an inference of high, and perceived sadness of low dominance, perceived happiness does not create such unambiguous impressions. To achieve a clearer image, the bases and level of perceived power, specifically reward power and expertise power, were taken into consideration, both of which could be either high or low. The study included 100
\end{abstract}

\footnotetext{
${ }^{4}$ Please cite as: Đorić, S. (2021). Efekat facijalne ekspresije emocija, tipa i nivoa moći na zaključivanje o dominantnosti opažene osobe [The effect of facial expression of emotion, type and level of power on inferences of perceived dominance]. Godišnjak za psihologiju, 18, 123-136. https://doi.org/ 10.46630/gpsi.18.2021.08
} 
participants (women $=71$ ), first and second year psychology students. The within subject $3 \times 2 \times 2$ design was used with Expression (happiness vs. anger vs. sadness) $\mathrm{x}$ Bases of power (reward power vs. expert power) x Level of power (high vs. low). Dominance was a dependent variable operationalized through the semantic differential scale. The stimuli were photographs of faces, controlled for gender and age, which displayed the aforementioned facial expressions. In the case of reward power, a significant expressed emotion $\mathrm{x}$ level of power interaction emerged. In the case of expert power, there was only signifficant main effect of facial expression on dominance perception. The findings were analyzed according to the various expectations of the participants, formed during the process of socialization. It could be concluded that for more insight into the mechanism which lies at the core of the effect that facial expression of emotions has on perceived dominance, the profession of the perceived individual also needs to be taken into consideration.

Key words: facial expression, bases of power, level of power, dominance

Primljeno: 24.03.2021. Primljena korekcija: 11.10.2021. Prihvaćeno za objavljivanje: 28.10.2021. 